\title{
WHOI-85-13
}

\section{Low-Rate Discharge of Various Electrochemical Batteries for Use with Oceanographic Instruments}

\author{
by
}

\author{
Alfred J. Ciesluk \\ Brian J. Guest \\ Craig D. Marquette \\ George H. Tupper
}

\begin{abstract}
Woods Hole Oceanographic Institution
Woods Hole, Massachusetts 02543
\end{abstract}

April 1985

Technical Report

Funding was provided by the Office of Naval Research under contract Number N00014-76-C-0197, NR 083-400.

Reproduction in whole or in part is permitted for any purpose of the United States Government. This report should be cited as:

Woods Hole Oceanog. Inst. Tech. Rept. WHOI-85-13.

Approved for publication; distribution unlimited.

\section{Approved for Distribution:}

\section{Robut CBeardsley}

Robert C. Beardsley, Acting Chairman

Department of Physical Oceanography 
TABLE OF CONTENTS

Introduction ........................ Page 1

Test Batteries . . . . . . . . . . . . . . . . . . . 1

1. Alkaline Cells .................. . . . . . 4 4

2. Mercury Cells . . . . . . . . . . . . . . . . . . . 4

3. Lithium Cells...................... . . . . . . . . 4

Test Description . . . . . . . . . . . . . . 6

Results and Discussion . . . . . . . . . . . . . 7

Conclusions . . . . . . . . . . . . . . . . . 21

Appendix

Battery Descriptions - Background . . . . . . . 22

Mercuric-Oxide Zinc . . . . . . . . . . . . . 22

Alkaline Manganese-Dioxide . . . . . . . . . . . . . . . . 24

Lithium Batteries . . . . . . . . . . . . . 25

Organic Lithium . . . . . . . . . . . . . . . . 27

Inorganic Lithium .................. . . . . . . . . . . 27

Acknowledgments . . . . . . . . . . . . . . . 28

Literature Cited . . . . . . . . . . . . . . . . 29

Bibliography . . . . . . . . . . . . . . . . 29 
LIST OF ILLUSTRATIONS

Figure

$\underline{\text { Page }}$

1. Batteries tested ................. . 3

2. Circuit used to discharge alkaline cells . . . . . . 8

3. Circuit used to discharge mercury and lithium cells . . 8

4. Discharge curves for Union Carbide alkaline " $D$ " cells discharged under various loads at $0^{\circ} \mathrm{C}$ and at room temperature 9

5. Discharge curves for Durace1l alkaline "D" cel1s discharged under various loads at $0^{\circ} \mathrm{C}$ and at room temperature . : . 10

6. Discharge curves for Duracell alkaline "F" cells discharged under various loads at $0^{\circ} \mathrm{C}$ and at room temperature . . . 11

7. Discharge curves comparing three alkaline cells discharged at $0^{\circ} \mathrm{C}$ under loads of 4 milliamperes and 40 milliamperes

8. Cell capacities of three alkaline cells at discharge load of 4 milliamperes at $0^{\circ} \mathrm{C}$ and at room temperature and at discharge load of 40 milliamperes at $0^{\circ} \mathrm{C}$. . . . . . 13

9. Discharge curves for Duracell mercury RM-42R cells discharged under an approximate 4 milliampere load (380 ohms) at $0^{\circ} \mathrm{C}$ and at room temperature . . . . . . . . . 14

10. Discharge curves for Duracel1 mercury RM-2550R cells discharged under an approximate 4 milliampere load (380 ohms) at $0^{\circ} \mathrm{C}$ and at room temperature . . . . . . . . 15

11. Discharge curves comparing $R M-2550 R$ and RM-42R mercury cells discharged under an approximate 4 milliampere load (380 ohms) at $0^{\circ} \mathrm{C}$. . . . . . . . . . . . 16

12. Cell capacities for RM-2550R and RM-42R mercury ce11s for various discharge rates and ambient temperatures . . . . 17

13. Discharge curves for GTE lithium thionyl-chloride "DD" cells discharged under an approximate 4 milliampere load (830 ohms) at $0^{\circ} \mathrm{C}$ and at room temperature ....... 18

14. Discharge curves for Electrochem Li/BCX "DD" cells discharged under an approximate 4 milliampere load (940 ohms) at $0^{\circ} \mathrm{C}$ and at room temperature . . . . . . . . . . 19

15. Cel1 capacities for GTE lithium thiony1-chloride and Electrochem $\mathrm{Li} / \mathrm{BCX}$ cells for various discharge loads at $0^{\circ} \mathrm{C}$ and at room temperature . . . . . . . . . 20 
$\underline{\text { Table }}$

1. Test Articles and Conditions . . . . . . . . . 2

2. Comparison of Battery-System Characteristics . . . 23 


\section{LOW-RATE DISCHARGE OF VARIOUS ELECTROCHEMICAL BATTERIES FOR USE WITH OCEANOGRAPHIC INSTRUMENTS}

Alfred J. Ciesluk, Brian J. Guest, Craig D. Marquette and George H. Tupper

\section{Abstract}

The endurance of self-sustained oceanographic instruments is generally limited to battery energy. Tests were initiated to measure the capacities of several types of electrochemical batteries when discharged at temperatures and rates typical of oceanographic use. Battery systems represented are alkaline-manganese dioxide, mercuric-oxide, and lithium sulphur oxychloride. Results of tests completed so far are presented. A brief overview of those batteries best suited for use with self-sustained oceanographic instruments is included as an appendix.

\section{Introduction}

Instruments which are self-sustaining have been widely used in oceanographic studies. The operating life of instruments of this kind is generally limited to battery energy. The capacities of most electrochemical batteries, however, can differ by as much as twenty-five percent from manufacturers' specifications when discharged at the low rates and near-freezing temperatures common in oceanographic use. The tests described in this report are being conducted to measure the capacities of several high energy density electrochemical batteries under these conditions.

of the many commercially produced types of batteries, those offering the highest energy densities at moderate cost are the alkaline-manganese dioxide, mercuric-oxide, and the lithium primary systems. Further information regarding selection of those batteries appears in the Appendix. The tests described in this report consisted of discharging individual cells of each of these types at single constant currents for an ambient temperature of approximately $0^{\circ} \mathrm{C}$. For comparison, corresponding tests were also run at room temperature. The mix of test articles and conditions is shown in Table 1. The tests were not intended to be comprehensive or statistically significant. Only one cell, chosen at random, was tested at each condition. Batteries were selected on the basis either of previously having provided good service with oceanographic instruments used by the WHOI Buoy Group or of having shown particular promise for oceanographic applications. Discharge loads were limited to the discrete levels shown in Table 1 . The effect of duty cycle, which can influence a cell's ability to deliver higher current on demand and overall cell life, was not investigated.

\section{Test Batteries}

Batteries tested are shown in Figure 1. Cell sizes are generally the largest commercially available for the various electrochemical systems represented. 
Table 1

TEST ARTICLES AND CONDITIONS

$\underline{0^{\circ} \mathrm{C} \text { Tests }} \underline{\text { Room Temperature Tests }}$

Load

Alkaline

Union Carbide
Union Carbide
Union Carbide
Durace11
Durace11
Durace11
Duracel1
Durace11
Duracel1

D

$\mathrm{D}$

D

$\mathrm{D}$

$\mathrm{D}$

D

F

$\mathrm{F}$

F
$1 \mathrm{~mA}$

$4 \mathrm{~mA}$

$40 \mathrm{~mA}$

$1 \mathrm{~mA}$

$4 \mathrm{~mA}$

$40 \mathrm{~mA}$

$1 \mathrm{~mA}$

$4 \mathrm{~mA}$

$40 \mathrm{~mA}$

Mercury
Durace11

Duracel1

Duracel1

Durace11

Duracel1

Durace11

D $(R M-42 R)$

D $(R M-42 R)$

D $(R M-42 R)$

RM-2550R

$\mathrm{RM}-2550 \mathrm{R}$

RM-2550R

$\underline{\text { Lithium }}$

GTE thionyl-chloride

GTE thionyl-chloride

GTE thiony1-chloride

Electrochem - Li/BCX

Electrochem - Li/BCX
DD

DD

$\mathrm{DD}$

DD

$\mathrm{DD}$
$1 \mathrm{~mA}$
$4 \mathrm{~mA}$
$40 \mathrm{~mA}$
$1 \mathrm{~mA}$
$4 \mathrm{~mA}$
$40 \mathrm{~mA}$

$1 \mathrm{~mA}$

$4 \mathrm{~mA}$

$40 \mathrm{~mA}$

$1 \mathrm{~mA}$

$4 \mathrm{~mA}$
$4 \mathrm{~mA}$

$4 \mathrm{~mA}$

$4 \mathrm{~mA}$

$4 \mathrm{~mA}$

$4 \mathrm{~mA}$

$4 \mathrm{ma}$ 
Union Carbide Alkaline "D"

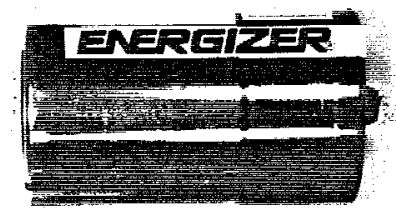

Duracell Alkaline "D"

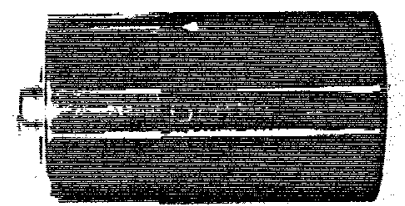

Duracell Alkaline " $F$ "

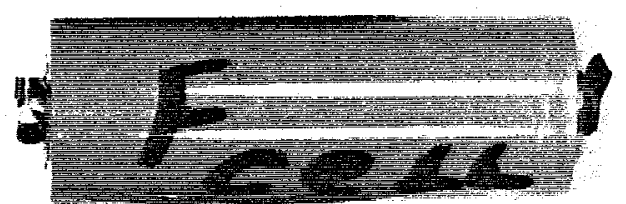

Duracell RM-2550R Mercury

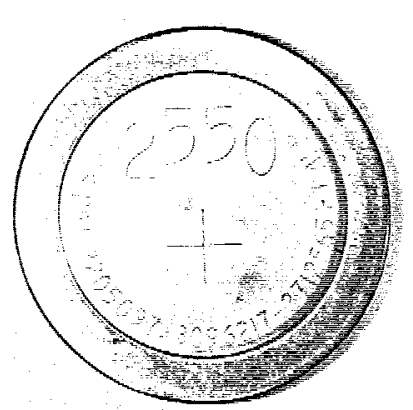

Duracell RM-42R Mercury

GTE Li/SOCl

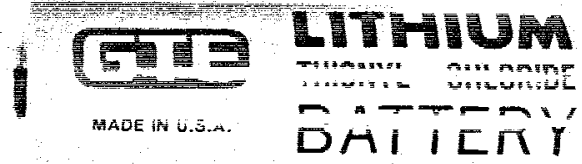

CAUTON BATTERYMAY EXPLODEIFAECHAACEO ON

Electrochem Li/BCX

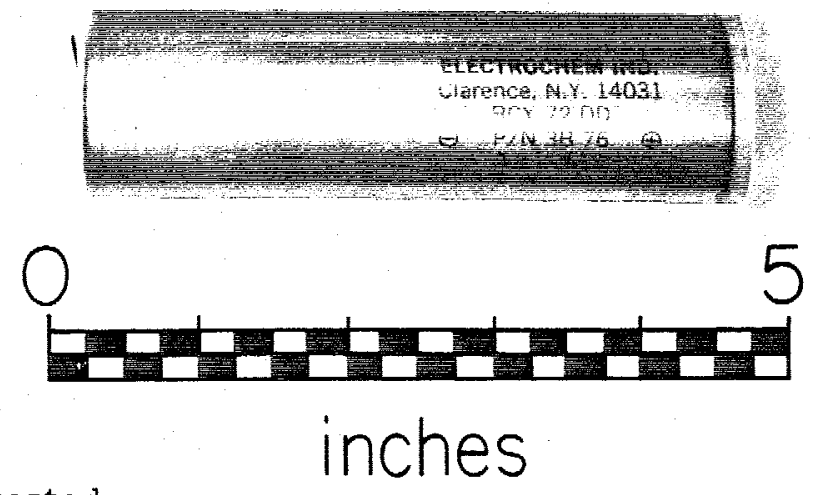

Fig. 1. Batteries tested 


\section{Alkaline Ce11s}

Union-Carbide Corporation and Duracell International, Inc. "D" size manganese dioxide (alkaline) cells have both been used extensively by the WHOI Buoy Group since 1970 with oceanographic instruments, and with good results. "F" size alkaline cells are relatively new. This test is the Buoy Group's first experience with them. The "F" cell's attraction is a potentially greater volumetric energy density than that of smaller alkaline cells.

The nominal voltage of an alkaline cell is 1.5 volts. During service, voltage declines gradually to a cutoff voltage between 0.7 and 0.9 volts at end-of-life. Upon reaching end-of-1ife, cell voltage quickly falls to approximately zero volts. Both Union-Carbide and Duracell alkaline "D" cells are nominal 10 ampere-hour cells. The Duracell "F" cell is rated for 20 ampere-hours.

\section{Mercury Ce11s}

Durace11 RM-2550R flat-disk mercury cells have been used almost exclusively by the WHOI Buoy Group since 1968 to power the receiver circuit in its many acoustic releases. They have generally provided good service. However, in recent years an increasing incidence of prematurely exhausted cells, most likely due to manufacturing errors, has compromised their otherwise good record. As a matter of fact, since this test program was begun, the Buoy Group has discontinued use of these batteries as power sources for our acoustic releases due to continued problems with premature discharge at sea. We have elected to use lithium batteries for all applications, either GTE's or the replacement which is sold by EG\&G Sea-Link Systems.

Mercury cells are constructed in the flat-disk shape specifically to improve the inherently poor low-temperature performance of the mercury electrochemical system. However, these cells do not pack together as well as standard cylindrical cells because of their relatively large cross-section.

Durace11 "D" sized RM-42R mercury cells were included in the test program because, with their smaller cross-section, they pack together better. Also, encouragement was provided by Duracell's prediction that these cells would not likely lose capacity when discharged at freezing temperatures if loads are small.

Both Durace11 RM-2550R and RM-42R mercury cells are nominal 1.35 volt cells. At room temperature, the RM-2550R cell is rated for thirteen ampere-hours, the $\mathrm{RM}-42 \mathrm{R}$ for fourteen ampere-hours.

\section{Lithium Ce11s}

Lithium batteries were first used with Buoy Group instruments in 1975 on a test basis. Those early Power Conversion, Inc. Iithium sulphur-dioxide batteries out-gassed during that test. Evaluation of lithium batteries was renewed in 1982 with the start of a two-year field test of several oceanographic instruments powered by state-of-the-art GTE Laboratories, Inc. 1ithium thionyl-chloride batteries. GTE cells were included in the test program described in this report to complement the two-year field test. 
GTE batteries were selected because, although they are a relatively low-rate battery, it was felt that they are the safest lithium batteries available. This claim is based on the following:

a. Low probability of internal short circuits: opposing electrodes are relatively well separated in GTE cells because of the bobbin-cell design used, and therefore are in little danger of coming in contact to cause internal short circuits. The likelihood of anode cathode contact is much greater for most other 1ithium cells because most other manufacturers use a wound (or "jelly-ro11") construction. In this design, anode and cathode are attached to opposite sides of a thin metal screen and rolled into a tight spiral. Any defect or penetration of the metal screen could bring opposing electrodes into contact causing internal short circuits.

b. Better heat dissipation: cell temperatures are better moderated in bobbin GTE cells. The bobbin design consists of a center-post cathode and thin peripheral cylindrical anode attached to the cell container. Heat produced internally during high rate or short circuit conditions is readily dissipated in both radial and axial directions. By comparison, wound cells are thermally well insulated because of their tight spiral construction. Cell temperatures are therefore much more likely to exceed the $180^{\circ} \mathrm{C}$ melting point of lithium which can lead to thermal runaway ending in cell venting or explosion.

c. Self-Limiting reaction during a continuous short-circuit load: anode surface area for a bobbin cell is typically a quarter that of a comparably sized wound cell. For bobbin cells, anode current densities will therefore be greater for any given load. For this reason, bobbin cells are limited to lower-current applications. However, because current densities are relatively high, the anode reaction will be vigorous enough during continuous short circuit conditions to quickly clog the anode with discharge products, effectively stopping overall cell reaction. Wound cells do not respond similarly. To account for short-circuit situations, most wound cells are equipped with an internal fuse.

d. Balanced ce11: for many early 1ithium cells, extended continuous discharge below zero volts, into voltage reversal, caused cells to overheat and rupture. The effects of voltage reversal can be eliminated by reducing the amount of 1 ithium to a 1:1 1ithium/electrolyte ratio - a lithium limited or "balanced" cell. Many modern lithium cells, including GTE 1ithium thiony1-chloride cells, are of this design.

The Electrochem Industries 1ithium bromine complex ( $\mathrm{Li} / \mathrm{BCX}$ ) cell was included in the test program as a possible future alternative to the GTE lithium ce11: Nominal voltage and "DD" size capacity are higher for the $\mathrm{Li} / \mathrm{BCX}$ cell - 3.9 volts and 30 ampere-hours versus 3.5 volts and 27 ampere-hours for the GTE 1ithium thiony1-chloride cell. Electrochem Li/BCX cells are wound cells. Although inherently not as safe, they offer a higher current capability and faster response to rapid load increases and can deliver full capacity in any cell orientation unlike the GTE cell which is orientation-sensitive. (McCartney, et al [1977] and D. Heckman of EG\&G Sea-Link Systems, Inc. [personal communication]) report reduction of cell capacities by as much as twenty-five percent for GTE cells discharged 
horizontally and as much as sixty percent when oriented vertically with the positive terminal downward.) Electrochem $\mathrm{Li} / \mathrm{BCX}$ cells are equipped with an internal fuse.

\section{Test Description}

Batteries tested and discharge conditions for each battery are shown in Table 1. The one-milliampere tests are ongoing; results of these tests are not presented in this report. Only one cell was tested at each separate condition. During the test all cells were oriented vertically, top end up.

In general, the plan was to discharge each of the different kinds of cells at several different fixed current loads, both at $0^{\circ} \mathrm{C}$ and at room temperature. For the alkaline cells, current was held constant by periodically adjusting a variable resistor connected in a series with each cell (Figure 2) to account for the characteristic voltage decline during discharge. In this manner, current was averaged to within a percent of the reported values.

For both mercury and 1ithium cells, output voltage is relatively stable during discharge. A fixed-resistance load like that shown in Figure 3 was used to approximate a fixed current load.

Ambient temperature was maintained to within one degree centigrade for the nominal $0^{\circ} \mathrm{C}$ cells except for a few minutes approximately each week when cells were removed from regrigeration to make status measurements. Room temperature cells saw a variation of plus or minus $6^{\circ} \mathrm{C}$ about a nominal temperature of $20^{\circ} \mathrm{C}$ during the test. No attempt was made to regulate humidity for either the freezing or room-temperature experiments. 
$\underline{\text { Results and Discussion }}$

Individual discharge curves of the various alkaline cells for each of the test conditions are shown in Figures 4-6. Composites comparing performance of each alkaline cell under a four milliampere load at $0^{\circ} \mathrm{C}$ appear in Figures 7 and 8 . (Circuit used to discharge alkaline cells is shown in Figure 2.)

In each of the tests completed so far, Duracell alkaline "D" cells provided more energy than Union-Carbide alkaline "D" cells. The difference is especially apparent in the four milliampere, $0^{\circ} \mathrm{C}$ data. For these conditions, assuming a one-volt end-of-1ife voltage, the Duracel1 cell provided 10.8 ampere-hours versus 9.1 ampere-hours for the Union Carbide cell.

The Duracell alkaline "F" cell delivered approximately twice as much energy as the nominal alkaline " $D$ " cell for each of the tests completed so far. The "F" cell is approximately one and one-half times large in volumethan the standard " $D$ " cell. Based on these results, the volumetric energy density of the Duracell "F" cell is, therefore, about a third greater than the nominal alkaline " $D$ " cell energy density.

Discharge curves comparing Durace11 flat-disk RM-2550R and "D"-size RM-42R mercury cells are shown in Figures $9-11$. RM-42 cells reached end-of-1ife sooner than RM-2550R, both at room temperature and $0^{\circ} \mathrm{C}$. At a nominal four-milliampere load, at $0^{\circ} \mathrm{C}$, the $\mathrm{RM}-42 \mathrm{R}$ cell delivered 11.2 ampere-hours versus 13.7 ampere-hours for the RM-2550R cell, a twenty-two percent difference. These results, therefore, do not support Duracell's prediction that their " $D$ "-size mercury cell will deliver full capacity (nominally fourteen ampere hours) when used at low rates and freezing temperatures. At room temperature, the RM-42R cell also delivered less energy than the flat-disk cell, which is contrary to expectation. Figure 12 shows cell capacities for RM-2550R and RM-42R. (Circuit used to discharge both mercury and lithium cells is shown in Figure 3.)

Data comparing performance of the GTE 1ithium thiony1-chloride cells and the Electrochem Li/BCX cells are shown in Figures 12 through 15. The most obvious feature of these data is the relative instability of output voltage exhibited by the Electrochem cells. Lithium cells, as a whole, were expected to show exceptional voltage stability during discharge, especially at low discharge rates.

The cell capacities for the Electrochem cells shown in Figure 15 are based on a two-volt end-of-life voltage, which is consistent with Electrochem's own criteria for determining end-of-life for the Li/BCX cell. GTE cells showed exceptional voltage stability during discharge; end-of-life voltage was typically four percent less than the fresh open circuit voltage.

As observed for both alkaline and mercury cells, GTE and Electrochem cells both provided more energy at $0^{\circ} \mathrm{C}$ than at room temperature, and more energy at the four-milliampere discharge rate than at 40 milliamperes.

Figures 2 and 3 show circuits used to discharge alkaline cells and mercury and 1ithium cells, respectively. 


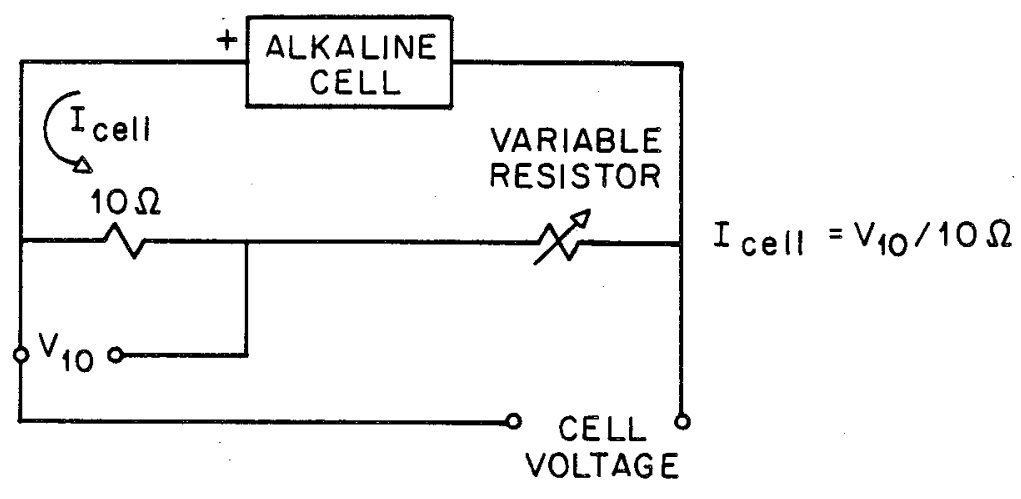

Fig. 2. Circuit used to discharge alkaline cells

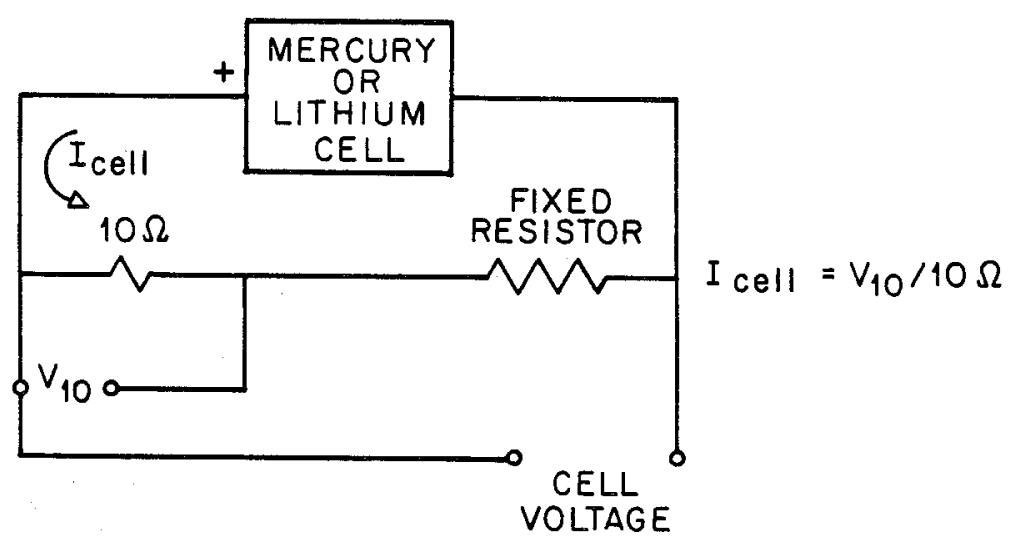

Fig.3. Circuit used to discharge mercury and lithium cells 


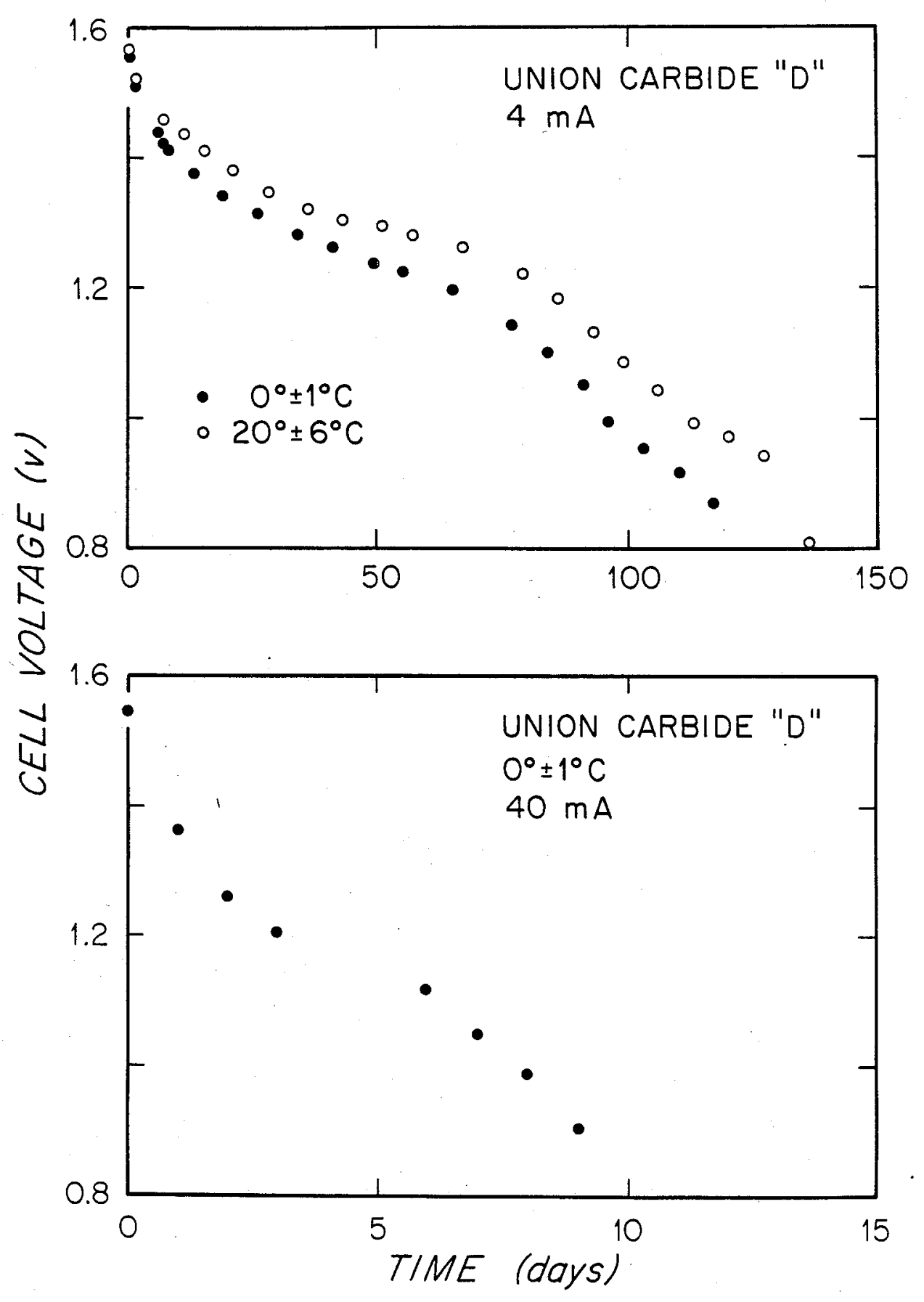

Fig. 4. Discharge curves for Union Carbide alkaline "D" cells discharged under various loads at $0^{\circ} \mathrm{C}$ and at room temperature 


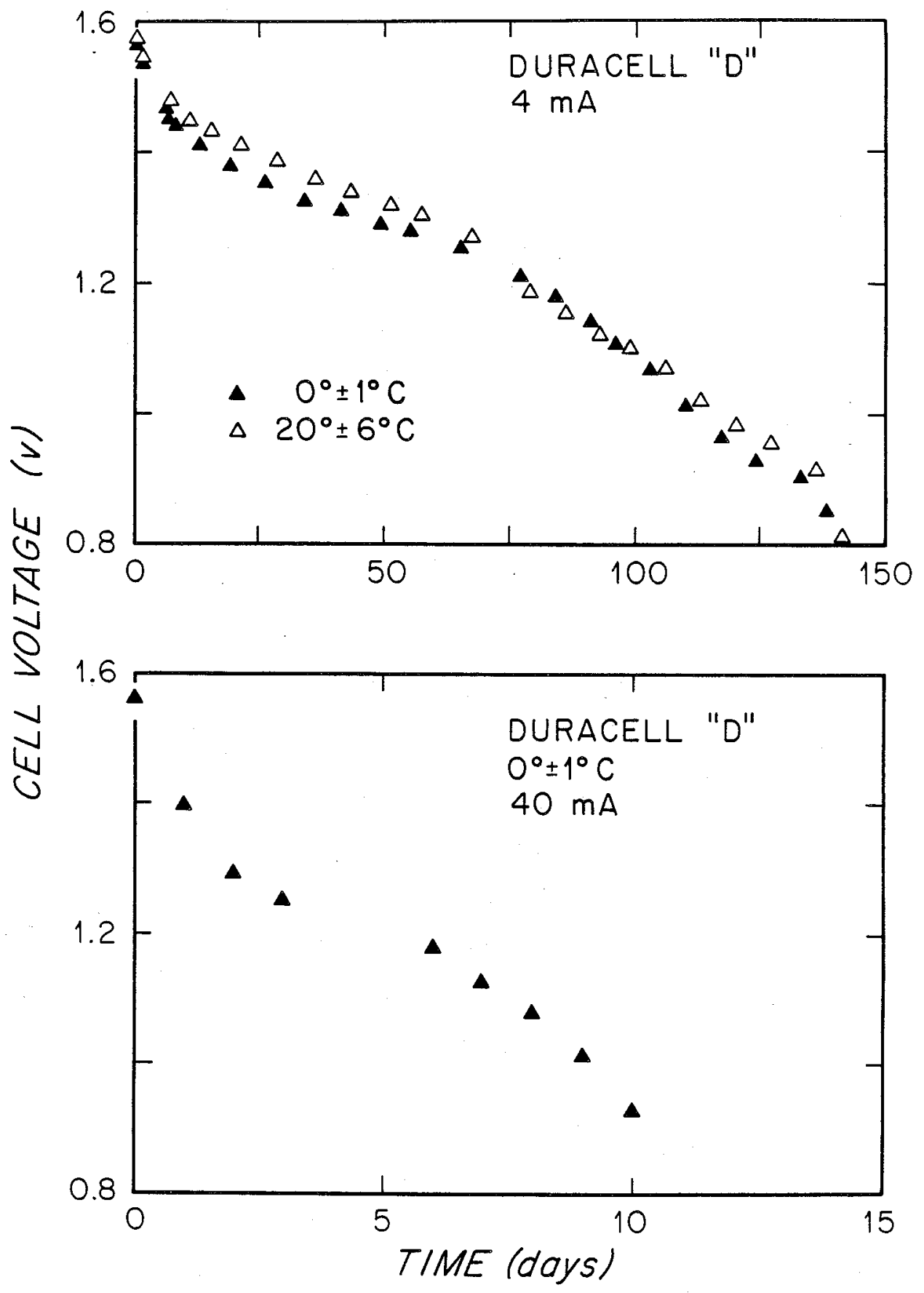

Fig. 5. Discharge curves for Duracell alkaline " $D$ " cells discharged under various loads at $0^{\circ} \mathrm{C}$ and at room temperature 


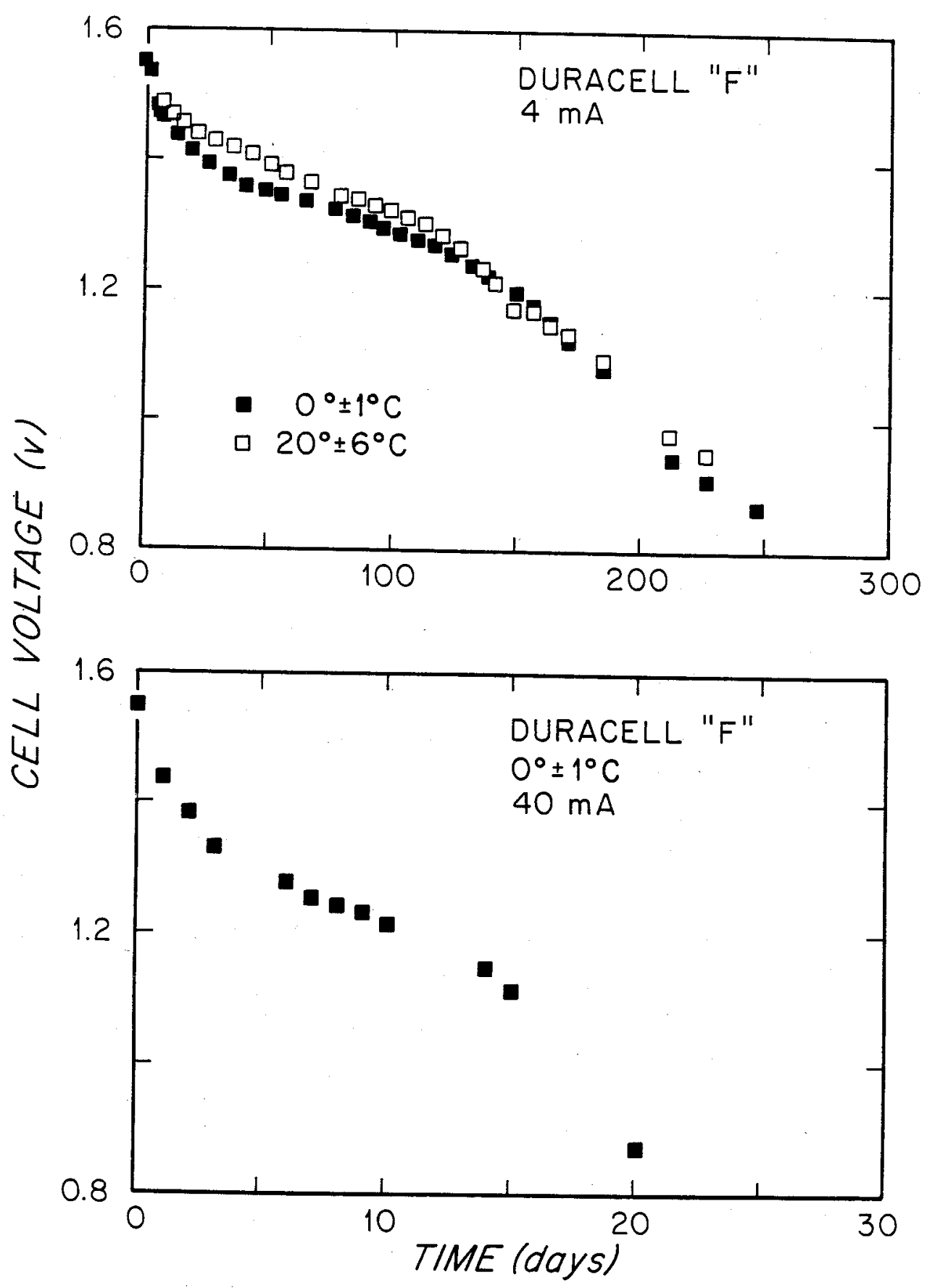

Fig. 6. Discharge curves for Duracell alkaline "F" cells discharged under various loads at $0^{\circ} \mathrm{C}$ and at room temperature 


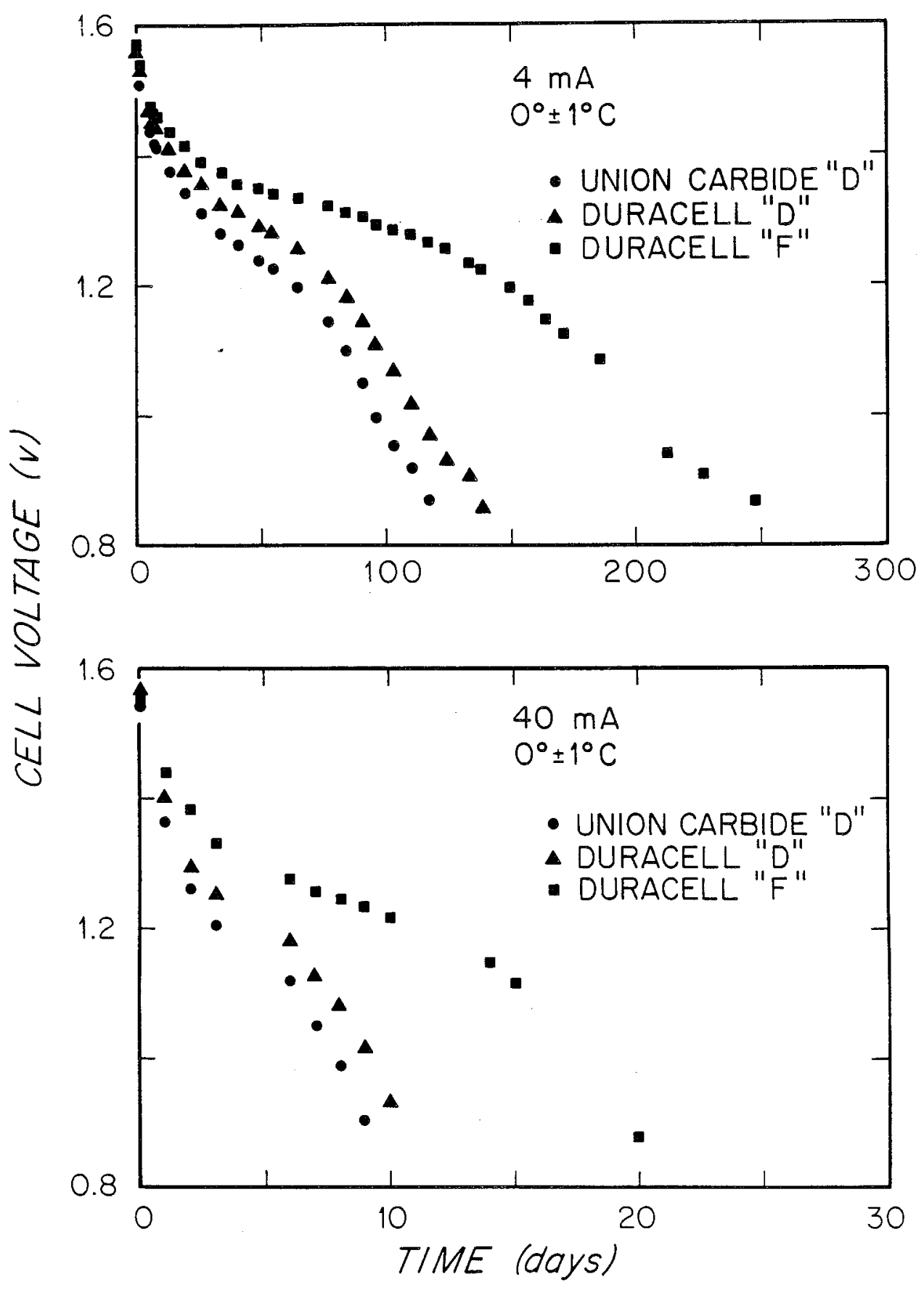

Fig. 7. Discharge curves comparing three alkaline cells discharged at $0^{\circ} \mathrm{C}$ under loads of 4 milliamperes and 40 millia mperes 


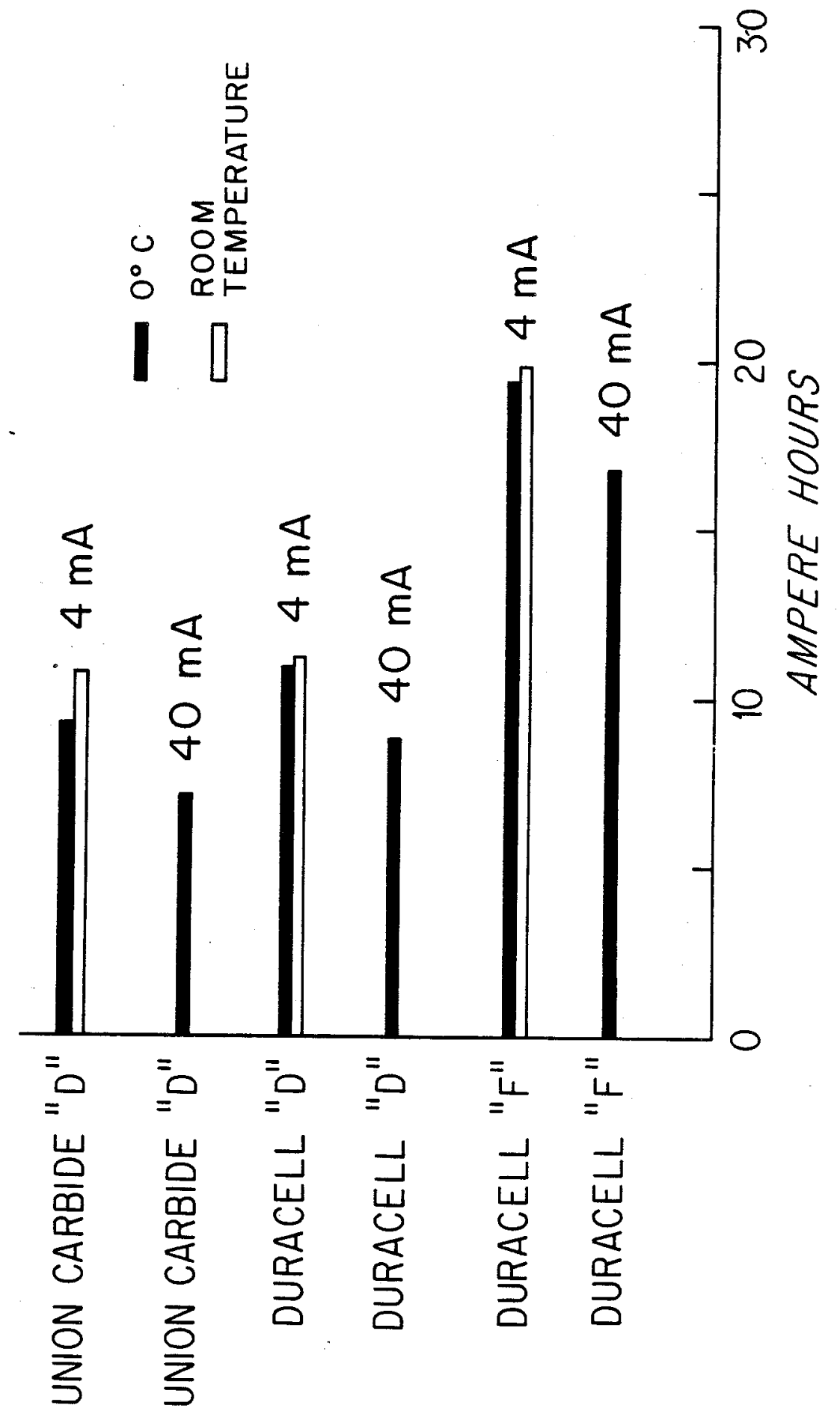

Fig. 8. Cell capacities of three alkaline cells at discharge load of 4 milliamperes at $0^{\circ}$ and at room temperature at discharge load of 40 milliamperes at $0^{\circ} \mathrm{C}$ 


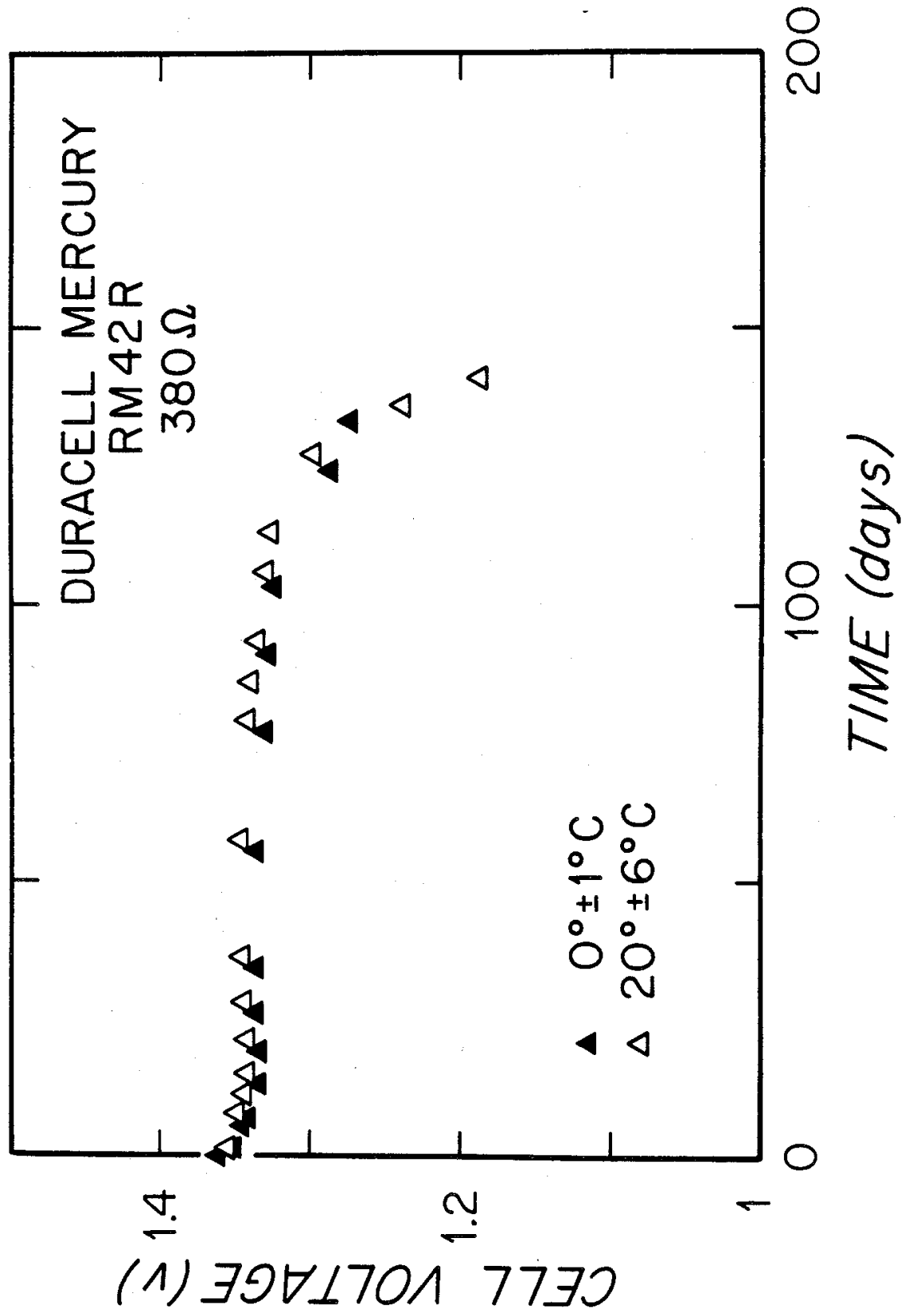

Fig. 9. Discharge curves for Duracell mercury RM-42R cells discharged under an approximate 4 milliampere load ( 380 ohms) at $0^{\circ} \mathrm{C}$ and at room temperature 


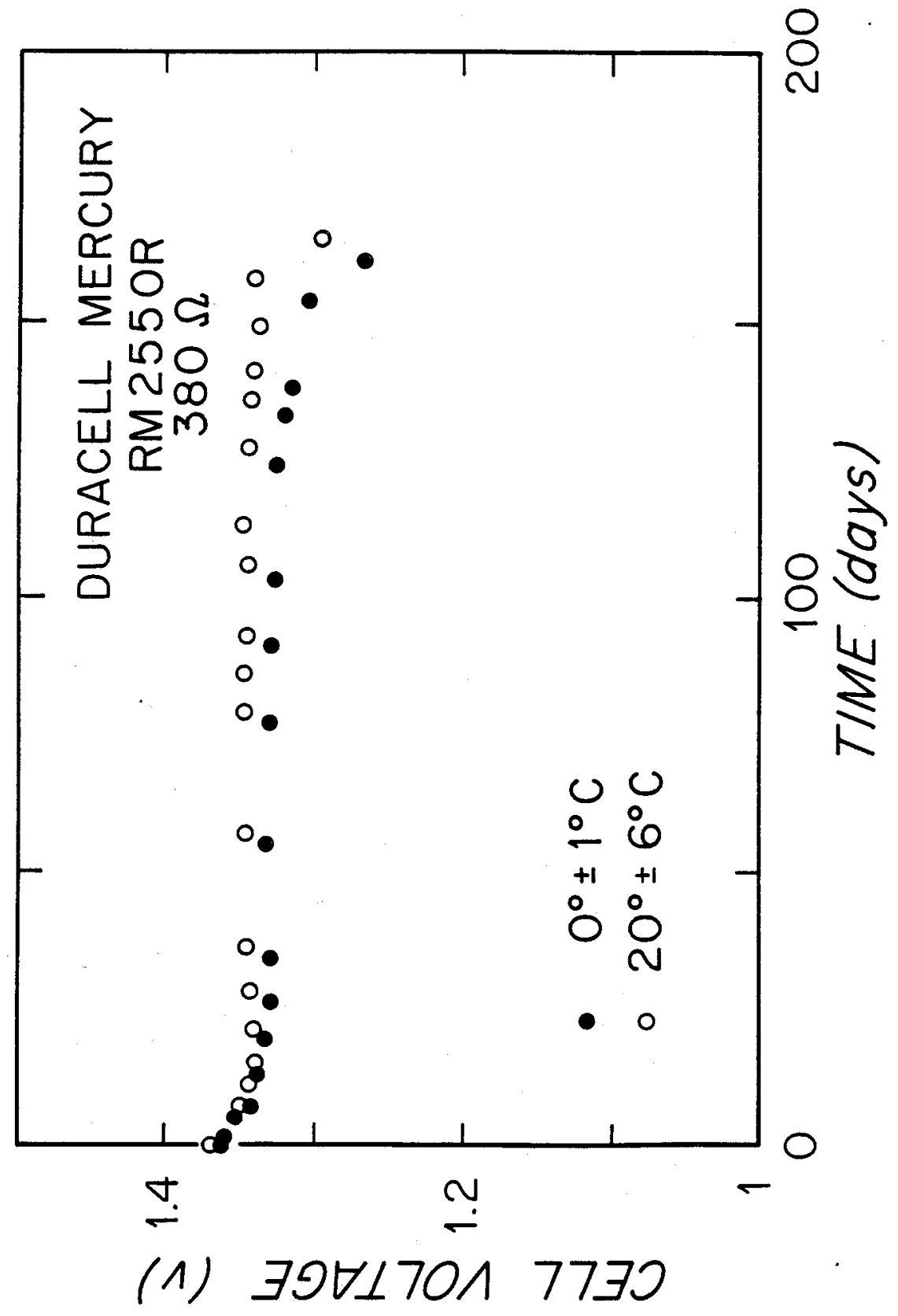

Fig. 10. Discharge curves for Duracell mercury RM-255OR cells discharged under an approximate 4 milliampere load (380 ohms) at $0^{\circ} \mathrm{C}$ and at room temperature 


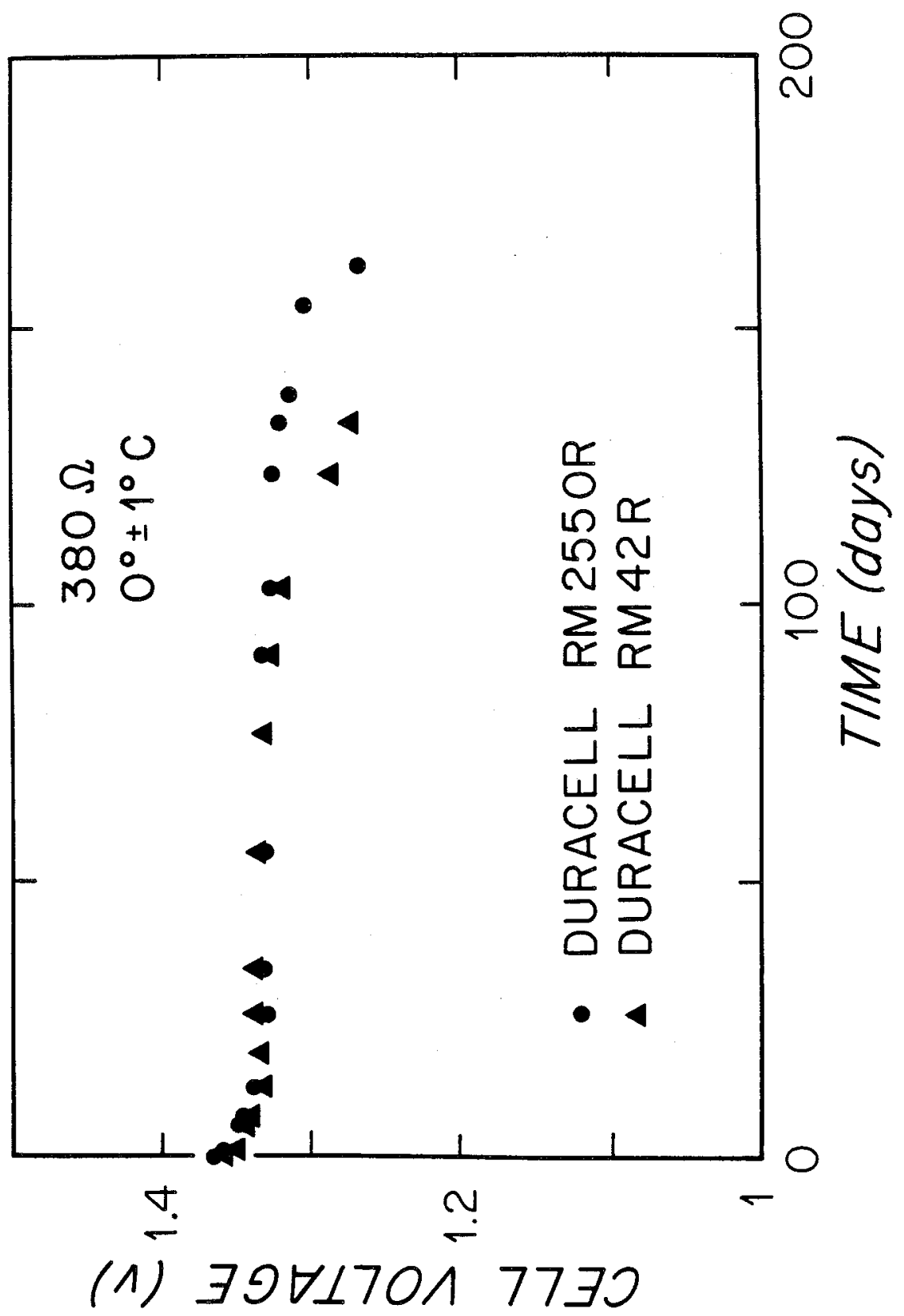

Fig. 11. Discharge curves comparing $R M-255 O R$ and $R M-42 R$. mercury cells discharged under an approximate 4 milliampere load ( $380 \mathrm{ohms})$ at $0^{\circ} \mathrm{C}$ 


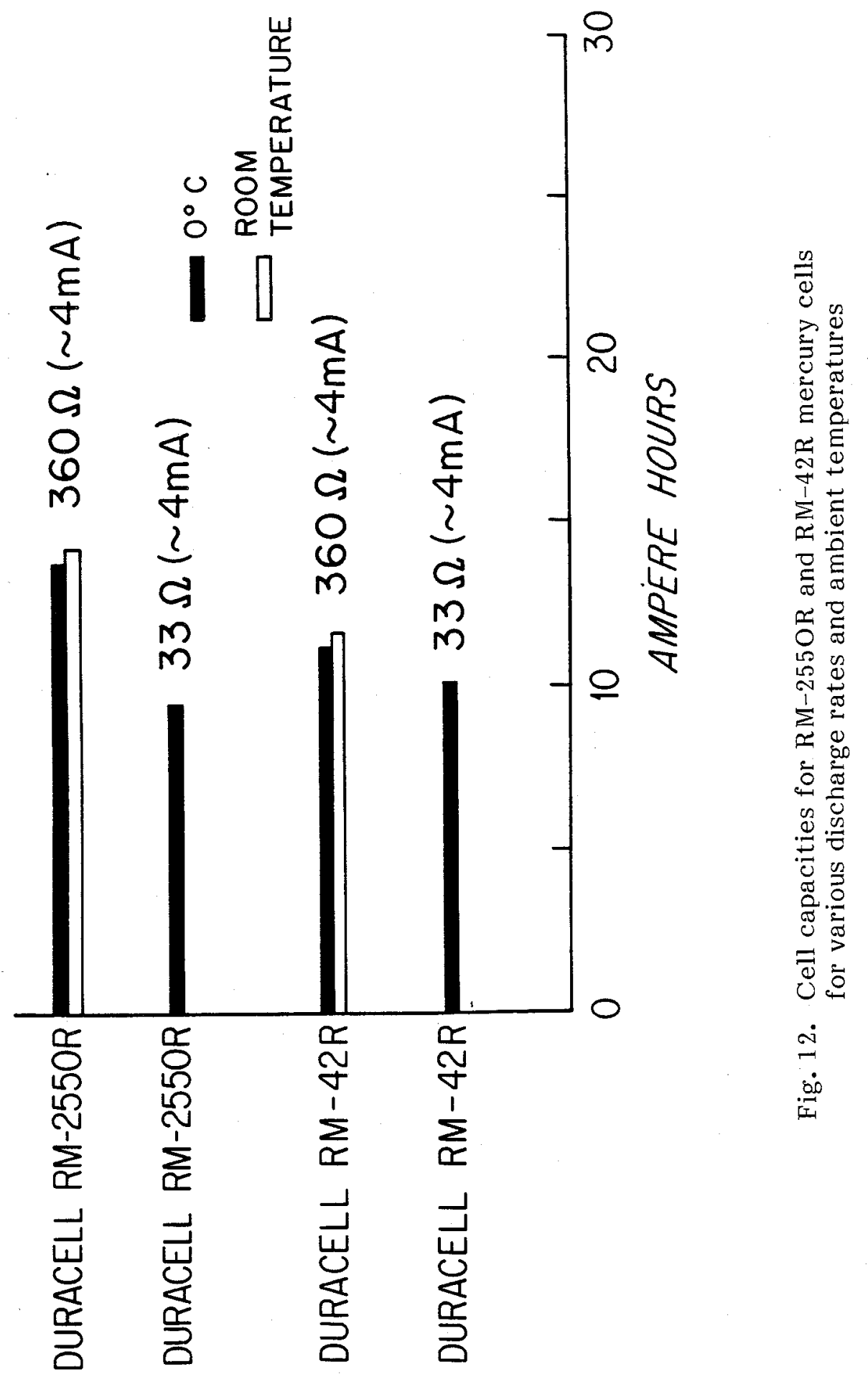




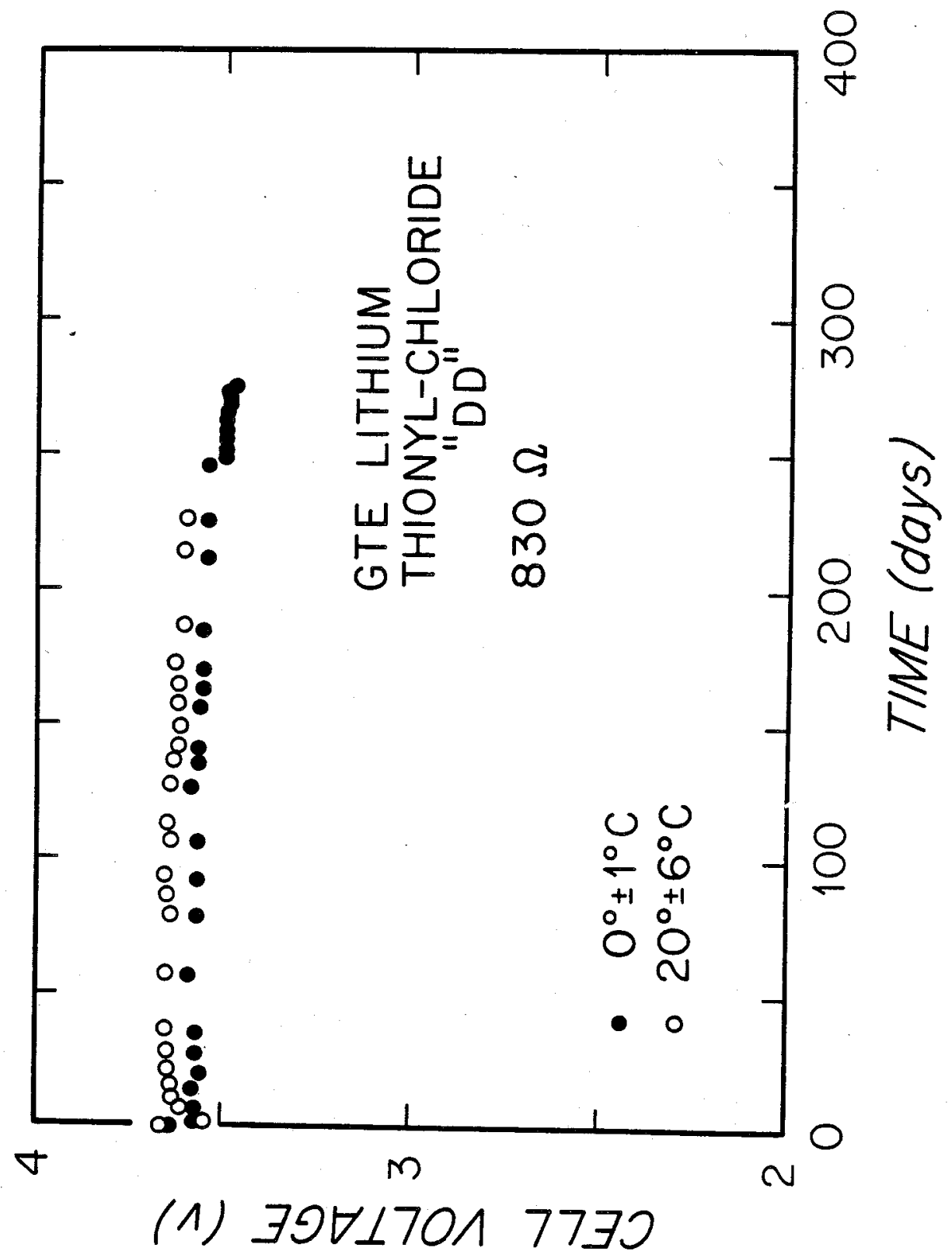

Fig. 13. Discharge curves for GTE lithium thionyl-chloride "DD" cells discharged under an approximate 4 milliampere load ( $830 \mathrm{ohms}$ ) at $0^{\circ} \mathrm{C}$ and at room temperature 


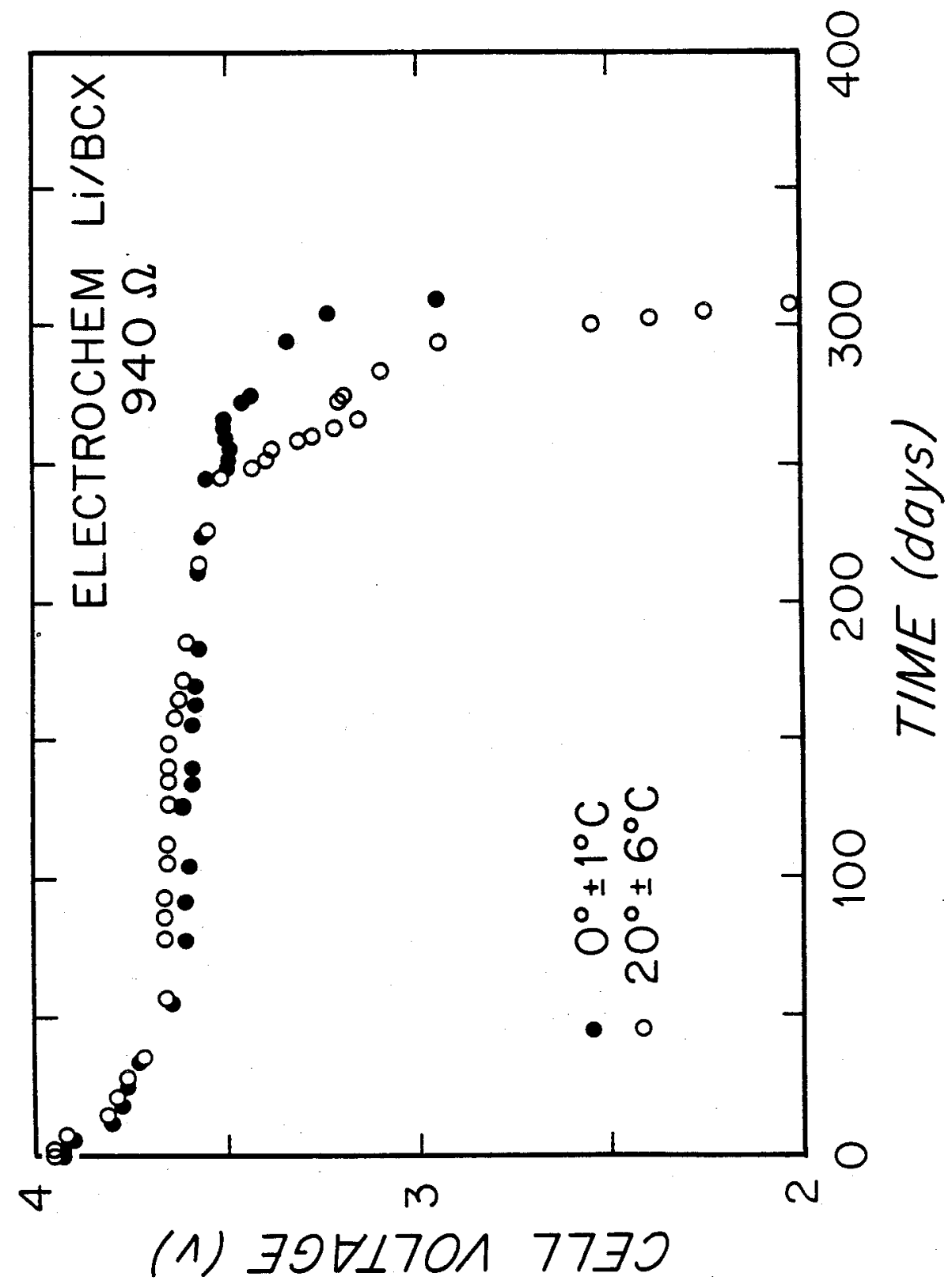

Fig. 14. Discharge curves for Electrochem Li/BCX "DD" cells discharged under an approximate 4 milliampere load (940 ohms) at $0^{\circ} \mathrm{C}$ and at room temperature 


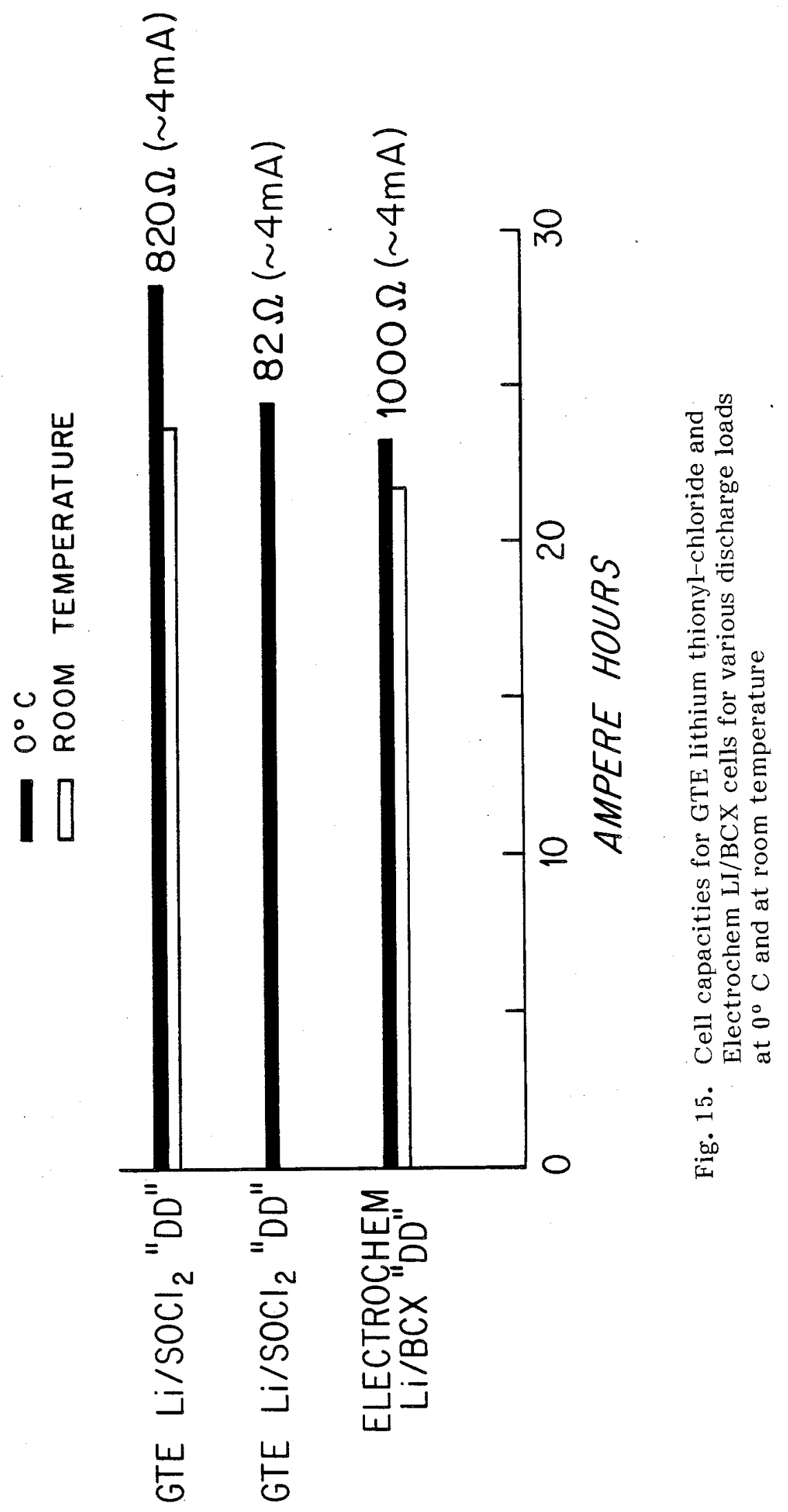




\section{Conclusions}

Duracel1 "D"-size alkaline cells delivered more energy than similar Union Carbide cells in each of the low-discharge-rate tests completed so far. The difference in capacity between these two cells for a four-milliampere load at $0^{\circ} \mathrm{C}$ was approximately twenty percent. Based on these results, Duracel1 " $D$ " cells are the clear choice between these two brands of alkaline cells.

Volumetric energy density of the Duracell alkaline " $F "$ cell was observed to be approximately a third greater than the nominal energy density of the alkaline " $D$ " cell. Provided their greater cell length doesn't prohibit their use, in applications requiring greater battery capacity, "F"-size alkaline batteries have a significant advantage over batteries made of smaller alkaline cells.

Durace11 "D"-size RM-42R mercury cells delivered less energy than volumetrically equivalent Duracel1 RM-2550R flat-disk mercury cells, both at room temperature and at $0^{\circ} \mathrm{C}$. At a load of four milliamperes at $0^{\circ} \mathrm{C}$, the difference in capacity between the two cells was approximately twenty-two percent. In applications requiring a mercury battery, the superior packing ability of the "D"-size cell may in some situations offset their relatively lower volumetric energy density. Otherwise, flat-disk mercury batteries should be specified.

GTE lithium thiony1-chloride "DD" cells delivered slightly more than their nominal twenty-seven hour capacity both at $0^{\circ} \mathrm{C}$ and room temperature, for loads of 4 milliamperes. Furthermore, output voltage was remarkably stable. By comparison, Electrochem Li/BCX "DD" cells exhibited a gradually declining output voltage during each of the low discharge rate tests completed so far. As such, their capacity is based on a two-volt end-of-life voltage which is approximately one-half the fresh open-circuit cell voltage. Based on these end-of-life criteria, at the four-milliampere discharge rate, at $0^{\circ} \mathrm{C}$, the Electrochem cell delivered approximately twenty-four ampere-hours.

Based on these results, in low-rate applications where a nearly vertical cell orientation can be maintained, GTE 1ithium thionyl-chloride batteries offer both superior performance and safety. 


\author{
Appendix \\ Review of Batteries for Use \\ with Self-Contained Oceanographic Instruments
}

Battery Descriptions - Background

Electrochemical batteries are the most efficient known devices for converting stored energy into usable electrical energy. They are generally classified into two groups based on the nature of their chemical reactions: primary batteries where the reaction is essentially irreversible and secondary batteries where it is reversible. Secondary batteries can be repeatedly rejuvenated by passing current through the battery in a direction opposite to that during discharge. In general, primary batteries are not designed for recharging; end of life is reached when they can no longer provide sufficient electrical energy following a single complete discharge. Energy densities for secondary batteries are generally much less than for primary batteries.

Table 2 compares various types of primary and secondary battery systems. Data represent optimum performance based on a composite of available manufacturers' literature and summary survey reports (McCartney, et al, 1977). The combined effect of shelf-1ife, self-discharge, low temperatures, cell orientation, and discharge rate could change these performance characteristics by twenty-five percent or more.

To qualify for use with oceanographic instruments where available space in most cases is restricted, as a minmimum, a battery must maintain a high energy-to-volume ratio at near-ambient freezing temperatures and have a long shelf life: of the commercially produced batteries, the mercuric-oxide, alkaline, magnesium, silver-zinc, and lithium systems qualify on this basis. Magnesium and silver-zinc batteries, however, are unattractive for most oceanographic applications, the former because of the hazard of hydrogen production during discharge and limited availability and the latter because of very high cost.

A brief description, then, of those battery systems best suited for oceanographic use - the mercuric-oxide, alkaline, and lithium systems follows :

\title{
Mercuric-0xide Zinc
}

The mercury primary system was developed in the 1940's to provide a battery with a better capacity-to-volume ratio and a longer storage life than the longstanding LeClanche (carbon-zinc) battery. A by-product of this development was a battery with a very stable voltage output.

The electrochemical system of the mercury battery consists of a mercuric-oxide cathode, an anode of pure amalgamated zinc, and a concentrated aqueous electrolyte of potassium hydroxide. The zinc anode usually also serves as the outer casing of the cell and is itself encased in a plated steel jacket. A molded plastic gasket is used to isolate the two from each other. 
Table 2

COMPARISON OF BATTERY-SYSTEM CHARACTERISTICS

Basic Cel1 Characteristics

System Volumetric

Vo1tage Energy Density Cost

(Volts) (Watt-hrs $\left./ \mathrm{cm}^{3}\right) \quad($ Watt-hrs $/ \$)$

$\begin{array}{llll}\text { Leclanche (P) } & 1.50 & 0.17 & 20.00 \\ \text { Mercuric 0xide (P) } & 1.35 & 0.37 & 1.90 \\ \text { Alkaline (P) } & 1.50 & 0.29 & 25.00 \\ \text { Magnesium (P) } & 2.00 & 0.23 & 12.00 \\ \text { Nicke1 Cadmium (S) } & 1.80 & 0.04 & 0.90 \\ \text { Lithium Inorganic (P) } & 3.60 & 0.90 & 3.50 \\ \text { Lithium Organic (P) } & 3.00 & 0.60 & 3.40 \\ \text { Silver Zinc (P) } & 1.50 & 0.26 & 1.40 \\ \text { Lead Silver (S) } & 2.00 & 0.05 & 11.00\end{array}$

$\mathrm{P}=$ Primary-type battery

S = Secondary-type battery 
Nominal cell voltage is 1.35 volts. Stable output voltage is an important characteristic of the mercury system providing voltage regulation without use of additional control circuitry. A stable voltage during discharge however does make determination of remaining battery energy before end of life difficult if not impossible. So far, none of the methods devised to make this measurement have been effective. Because of this problem, and because of our recent experiences with premature discharge and resulting equipment losses, we in the WHOI Buoy Group have discontinued use of these batteries as power sources for our acoustic releases.

Mercury cells are made in many of the standard international cylindrical sizes by several manufacturers, and also in a flat disk shape using a wound anode by Duracel1, Inc. The flat-disk wound-cel1 construction, by virtue of an anode of proportionally larger surface area, offers significantly better low-temperature performance. Cells of this type can deliver full capacity at $0^{\circ} \mathrm{F}$ for continuous currents less than 50 milliamperes. At temperatures much below freezing, service capacities of flat-disk cells can be expected to drop by as much as fifty percent.

Mercury batteries have excellent shelf life retaining upwards of ninety percent of full capacity after one year of storage at room temperature. This period can possibly be extended to as long as five years with storage at near-freezing temperatures.

\section{Alkaline Manganese-Dioxide}

Alkaline batteries were introduced in the early $1960^{\prime} \mathrm{s}$ almost twenty years after the mercury batteries. They are much more economical, supplying about seventy-five percent as much energy as the comparably sized mercury battery but at less than twenty percent of the cost. The alkaline system is also better suited for use at low temperature, giving relatively good service to as $10 \mathrm{w}$ as $-20^{\circ} \mathrm{C}$.

Electrochemically, the alkaline system consists of a zinc anode of large surface area, a high-density manganese-oxide cathode, and a potassium-hydroxide electrolyte. Individual cells are hermetically sealed and encased in a steel jacket. Cells are available in a wide range of sizes including the five main international sizes and also, recently, in the "F" size which is fifty percent larger than the standard "D" size.

The open circuit voltage of fresh alkaline cells is, typically, slightly higher than 1.5 volts. During service, voltage declines gradually in a non-linear fashion as a function of depth of discharge to a cutoff between 0.9 and 0.7 volts which spells end of life. The closed-circuit voltage during service is therefore a measure of remaining energy, in this respect a clear advantage of the alkaline system. On the other hand, alkaline batteries are disadvantaged in applications requiring voltage stability.

Alkaline batteries can be stored for extended periods without serious loss of capacity. They can retain as much as ninety-five percent of fresh cell capacity after being stored for one year at room temperature. This period may possibly be increased to several years with storage at freezing temperatures. 


\section{Lithium Batteries}

The term "1ithium battery" actually refers to a family of electrochemical systems all using lithium anodes. They are relatively new, having been introduced commercially only ten years ago. Lithium batteries are usually divided into two groups - the organic or sulphur dioxide cell with its organic electrolyte sulphur dioxide, and the inorganic lithium cells which use liquid oxyhalides such as thionyl chloride or sulfuryl chloride as an electrolyte. Further distinctions between the two groups are addressed after the discussion of properties common to all 1ithium batteries immediately following.

As a group, lithium batteries offer the highest electrochemical energy densities; they are lighter and can operate over a far greater temperature range $\left(-54^{\circ} \mathrm{C}\right.$ to $\left.73^{\circ} \mathrm{C}\right)$ than other batteries; they maintain a very stable output voltage and have a remarkably long projected shelf life of up to ten years. Today, with increasing competition among manufacturers, their cost is competitive on an energy-per-dollar basis with other types of batteries.

If lithium batteries, despite their superior performance characteristics, have only recently started to gain general acceptance, it is because of a concern for safety. The source of much of this restraint has been several early incidents involving explosions which received considerable publicity. Much of the industry's efforts have necessarily been directed toward making lithium batteries safer even at the expense of performance.

Because of their exceptional energy densities and the highly reactive nature of 1 ithium itself, lithium batteries are, nevertheless, inherently more dangerous than other types of batteries. For this and other reasons related to battery performance, as well as safety during transport, the need to observe the following precautions should be considered when selecting lithium batteries and precautions should be taken to avoid the following areas of operation: a. Short-circuit and high-current discharge: lithium cells are relatively low-resistance systems and some, especially those with proportionally large anode surface areas, are capable of delivering several amperes of current during continuous operation and slighly higher levels when pulsed. However, under high-current and short-circuit conditions cells may overheat and then vent, releasing toxic and corrosive gases. Under these circumstances there is the danger that internal temperatures will exceed the melting point of lithium ( 1 ithium melts at $180^{\circ}$ C) which will cause lithium to flow and react with other cell components at a rapid rate. This runaway reaction increases temperature even further, causing a cell to either vent or explode violently. To prevent this from occurring some cells are equipped with an internal fuse to limit the current level during discharge.

b. Overheating: 1ithium batteries can be stored and operated at temperatures up to $160^{\circ} \mathrm{F}$. However, for the reasons stated above, ambient temperatures approaching the melting point of lithium should be avoided. Likewise, as with other primary batteries, lithium cells should not be incinerated. 
c. Over- or forced discharge: extended continuous discharge of a cell below zero volts, into voltage reversal, especially at high discharge rates, can cause cells to overheat and rupture. It has been reported (Liang, et al, 1980) that some kinds of lithium cells tend to become percussion-sensitive after prolonged forced over-discharge.

A related situation may arise any time a cell is recharged by being connected to a higher-voltage power source of like or opposite polarity. Forcing an external current though a-cell in this manner also may cause overheating. Diode protection is a simple way to prevent such an occurrence and should be specified when cells are connected together or to power supplies.

The effects of voltage reversal can be reduced significantly by designing cells with a stoichiometric ratio of 1 ithium of about $1: 1$ rather than excess lithium used in many early designs (Ralston, 1980). Today many of the commercially produced lithium systems not specifically designed for high-rate application are of this 1ithium-limited design.

d. Voltage delay and self-discharge: 1ithium batteries, particularly when first used at low temperatures and high rates after long inactive periods, may exhibit a "voltage delay", i.e., the battery voltage is below the specified cut-off voltage. This condition will usually not persist longer than a few minutes. Full voltage is restored by discharging a battery at the specified load until operating voltage is reached. Generally, no appreciable voltage delay will occur for low-rate discharge of batteries stored or used at or above room temperature.

The mechanism responsible for voltage delay - a thermodynamic instability common to all lithium anode systems which favors the formation of a passivating film over the anode surface - has further consequences, most importantly a loss in cell capacity through self-discharge.

Typical anode surface areas are $400 \mathrm{~cm}^{2}$ for wound "DD" cells and $100 \mathrm{~cm}^{2}$ for bobbin "DD"s. In the absence of discharge current a thin self-limiting passivating film will rapidly form on the lithium anode surface. At low discharge rates (those with anode current densities less than approximately 10 microamperes $/ \mathrm{cm}^{2}$ ) the passivating film is sufficiently porous to permit the migration of enough ions to sustain current and yet remain undisturbed. This self-discharge reaction will remain dormant until a load is applied to the cell. Under low current conditions, then, cell capacity is little affected by self-discharge. If the discharge rate is increased, the higher flux of moving ions will disrupt the passivating film, lowering cell resistance but increasing self-discharge. At even higher rates the film may break up completely causing lower cell resistance but increasing self-discharge further. Because the passivating film does not break down immediately there is a lag in performance when discharge quickly changes to a high rate.

The loss of capacity through self-discharge may be exaggerated when loads are pulsed or otherwise vary in time. Duty cycle and peak load will determine the extent of loss under these conditions. 
Some cell designs can reduce self-discharge and voltage delay. In the larger commercial sizes lithium cells are constructed in two configurations - bobbin and wound. Generally the wound configuration provides the largest electrode surface area per volume with an anode surface area at least several times greater than that of a bobbin cell. At a given discharge rate, the current density at a wound electrode is therefore much lower than at a bobbin electrode. Since self-discharge and voltage delay are directly" proportional to current density, wound cells are superior in this respect.

e. Transportation: U.S. domestic transport of Iithium batteries is regulated by the Department of Transportation through DOT-E-7052. Lithium cells containing 0.5 grams or less 1ithium are unregulated. All other 1ithium cells must carry warnings, have proper packaging, and be transported by approved land, sea, or air methods as stipulated in DOT-E-7052. Generally, lithium batteries having more than 0.5 grams of lithium are prohibited from passenger aircraft. It should be noted that transportation of cells or batteries containing more than 500 grams of lithium is not permitted under DOT-E-7052.

Internationally, air transportation is regulated by the International Air transport Association and the International Civil Aviation Organization in a similar manner.

Organic Lithium

The organic lithium system was the first 1ithium system available on a commercial basis. The principal parts of an organic lithium cell are a lithium anode, a carbon cathode, and an organic electrolyte of liquid sulphur dioxide. Organic lithium cells are normally fabricated in a cylindrical structure using the wound (or "jelly-rol1") design. System voltage is nominally three volts; energy density is approximately $0.5 \mathrm{watt}-\mathrm{hrs} / \mathrm{cm}^{3}$. Nominal "DD" ce11 capacity is twenty-one ampere hours.

Organic 1ithium cells are usually internally pressurized to between two and three atmospheres. A vent is provided to relieve pressure if the internal pressure reaches an excessive level (typically twenty-five atmospheres). Sulphur dioxide and other volatile reaction products are released during venting. Cells are available in a range of sizes including the main international sizes and also in a "DD" size which is twice as long as the standard "D" size.

Inorganic Lithium

There are many different inorganic lithium systems available commercially. In generaly, voltages and capacities are higher for inorganic systems than for the organic system. Inorganic system voltages range from typically 3.5 to almost 4 volts; energy densities from 0.8 to 1.1 watt-hrs $/ \mathrm{cm}^{3}$. "DD" cell capacities vary from 25 to 30 ampere-hours.

Most inorganic cells use the wound form of construction. An important exception are the GTE 1ithium thionyl-chloride cells which use the bobbin design. Inorganic 1ithium cells, unlike organic lithium cells, are not internally pressurized.

Inorganic 1ithium cells are available in many of the standard sizes, including the "DD" size. 


\section{Acknowledgements}

The authors gratefully acknowledge the assistance of J.P. Dean who provided guidance and helpful suggestions, and Elizabeth D. Guillard who both proficiently edited and typed the many drafts of this report.

The work described herein was funded by the Office of Naval Research, Contract N00014-76-C-0197, NR 083-400. 


\section{Literature Cited}

Liang, C. C., P. W. Kreh1 and D. A. Danner. 1980. Bromine chloride as a cathode component in lithium inorganic cells. J. Appli. Electrochem. 11: $563-571$

McCartney, J. F., W. H. Shipman, C. R. Gunderson and C. W. Koehler. 1977. Development of lithium inorganic electrolyte batteries for Navy applications, NUCTP564 (tech. pub.), Naval Undersea Center, San Diego, Calif.

Murphy, R. M., P. W. Kreh1 and C. C. Liang. 1981. The effect of halogen addition on the performance characteristics of lithium/sulfur oxychloride battery systems. Proc. 16th Intersociety Energy Conversion Engineering Conference, Vo1. 1, Amer. Soc. Mech. Eng., N.Y., N.Y., pp. 97-101

Ralston, R. E. 1980. Recent advances in $\mathrm{LiSO}_{2}$ battery technology. Proc. 29th Power Sources Conference, The Electrochemical Society, Inc., Pennington, N.J., pp. 112-114

\section{Bibliography}

The following papers are published in Proceedings of the 29th Power Sources Conference, June 9-13, 1980, Atlantic City, N.J., The Electrochemical Society, Inc., Pennington, N.J.:

Abraham, K. M. and R. M. Mank. Some safety related chemistry of $\mathrm{Li} / \mathrm{SOC} 1_{2}$ cells

Babai, M., and U. Zak. Safety aspects of low-rate $\mathrm{Li} / \mathrm{SOCl}_{2}$ cells

Dallek, S., S. D. James and W. P. Kilroy. Thermal studies of reactivity in the lithium-thiony1 chloride and lithium-sulfur dioxide battery sys tems

Hazkany, E. Peled and B. Raz. Primary cells - a forecast of performance

Johnson, L. J. and A. H. Willis. User safety considerations in lithium thionyl chloride batteries

Klinedinst, K. A. Cathode-1imited $\mathrm{Li} / \mathrm{SOCl}_{2}$ cells

Langrish, L. W. A comparison of the primary 1ithium systems

Ralston, R. E. Recent advances in $\mathrm{LiSO}_{2}$ battery technology

Reiss, E. H., Jr. Considerations in the use and handling of lithium-sulfur dioxide batteries 
Rosansky, M. G. and T. Watson. Manufacture of high reliability lithium sulfur-dioxide batteries

Rupancic, R. L., L. F. Urry and V. S. Alberto. Performance and safety characteristics of small cylindrical $\mathrm{Li} / \mathrm{SOCl}_{2}$ cells 
uthor(s) Alfred J. Ciesluk, Brian J. Guest, Craig D. Marquette and eorge H. Tupper

enforming Organization Name and Address

oods Hole Oceanographic Institution

oods Hole, Massachusetts 02543

The endurance of self-sustained oceanographic instruments is generally limited to battery nergy. Tests were initiated to measure the capacities of several types of electrochemical batteries hen discharged at temperatures and rates typical of oceanographic use. Battery systems represnted are alkaline-manganese dioxide, mercuric-oxide, and lithium-sulphur oxychloride. Results f tests completed so far are presented. A brief overview of those batteries best suited for use ith self-sustained oceanographic instruments is included as an appendix.

Document Analysis a. Descriptors

- Battery tests

$\therefore$ Oceanographic power sources, low discharge-rate

i. Deep-sea instrumentation

b. Identifiers/Open-Ended Terms

19. Security Class (This Report) UNCLASSIFIED

20. Socurity Class (This Page)
21. No. of Pages 30 22. Price 


\section{DOCUMENT LIBRARY}

November 30, 1984

\section{DISTRIBUTION LIST FOR TECHNICAL REPORT EXCHANGE}

Institute of Marine Sciences Library

University of Alaska

O'Neill Building

905 Koyukuk Ave., North

Fairbanks, AK

Attn: Stella Sanchez-Wade

Documents Section

Scripps Institution of Oceanography

Library, Mail Code C-075C

La Jolla, CA 92093

Hancock Library of Biology \& Oceanography

Alan Hancock Laboratory

University of Southern California

Los Angeles, CA 90007

Gifts \& Exchanges

Library

Bedford Institute of Oceanography

P.O. Box 1006

Dartmouth, NS, B2Y 4A2, CANADA

Office of the International

Ice Patrol

c/o Coast Guard R \& D Center

Avery Point

Groton, CT 06340

Library

Physical Oceanographic Laboratory

Nova University

8000 N. Ocean Drive

Dania, FL 33304

NOAA/EDIS Miami Library Center 4301 Rickenbacker Causeway

Miami, FL 33149

Library

Skidaway Institute of Oceanography

P.O. Box 13687

Savannah, GA 31416

Institute of Geophysics

University of Hawaii

Library Room 252

2525 Correa Road

Honolulu, HI 96822
Library

Chesapeake Bay Institute

4800 Atwell Road

Shady Side; MD 20876

MIT Libraries

Serial Journal Room 14E-210

Cambridge, MA 02139

Director, Ralph M. Parsons Laboratory

Room 48-311

MIT

Cambridge, MA 02139

Marine Resources Information Center Bldg. E38-320

MIT

Cambridge, MA 02139

Library

Lamont-Doherty Geological Observatory

Colombia University

Palisades, NY 10964

Library

Serials Department

Oregon State University

Corvallis, OR 97331

Pell Marine Science Library

University of Rhode Island

Narragansett Bay Campus

Narragansett, RI 02882

Working Collection

Texas A\&M University

Dept. of Oceanography

College Station, TX 77843

Library

Virginia Institute of Marine Science

Gloucester Point, VA 23062

Fisheries-Oceanography Library 151 Oceanography Teaching Bldg.

University of Washington

Seattle, WA 98195

Library

R.S.M.A.S.

University of Miami

4600 Rickenbacker Causeway

Miami, FL 33149 